\title{
Analysis of article 69-B of the CFF and the tax culture
}

\section{Análisis del artículo 69-B del CFF y la cultura tributaria}

\author{
ANDRADE-OSEGUERA, Miguel Ángel†*, PAREDES-BARRÓN, Adriana and BÁRCENAS- \\ PUENTE, José Luis
}

Universidad Tecnológica del Suroeste de Guanajuato. Mexico.

ID $1^{\text {st }}$ Author: Miguel Ángel, Andrade-Oseguera / ORC ID: 0000-0002-7926-9162, Researcher ID Thomson: S-6586-2018, CVU CONACYT ID: 509374 ID $1^{\text {st }}$ Co-author: Adriana, Paredes-Barrón / Researcher ID Thomson: S-6586-2018, arXiv Author ID: 73Y8LW-FGQ28,
CVU CONACYT ID: 947184

ID $2^{\text {nd }}$ Co-author: José Luis, Bárcenas-Puente / ORC ID: 0000-0002-1051-8861, Researcher ID Thomson: S-8603-2018, CVU CONACYT ID: 743962

DOI: $10.35429 / J I E C .2020 .6 .4 .1 .7$

Received January 10, 2020; Accepted June 30, 2020

\begin{abstract}
The economic situation in our country, the emergence of new companies and the disappearance of others, makes many taxpayers resort to unconventional strategies, in order to avoid compliance with tax obligations as established in the regulations, to improve their finances, This, many of the times they do it by resorting to some figures inherent to evasion practices, those that imitate and others that give tax effects, the authority colloquially calls them EFOS and EDOS, Companies that Invoice Simulated Operations and Companies that Deduct Simulated Operations . The taxpayer who resorts to the use of this evasion practice and who is identified by the competent authority, will have to abide by the procedure established in article 69-B of the Federal Tax Code. The work shows the analysis of this procedure, and the relationship that it has with an adequate Tax Culture, through the implementation of an adequate Fiscal Citizenship.
\end{abstract}

Tax culture, Contributions, Taxes, EFOS, EDOS

\begin{abstract}
Resumen
La situación económica que se vive en nuestro país, el surgimiento nuevas empresas y desaparición de otras, hace que muchos contribuyentes recurran a estrategias poco convencionales, para poder evitar el cumplimiento de las obligaciones tributarias conforme a lo establecido en la normatividad, para mejorar sus finanzas, esto, muchas de las veces lo realizan recurriendo a algunas figuras inherentes a las prácticas de evasión, aquellas que imiten y otras que dan efectos fiscales, la autoridad las denomina coloquialmente EFOS y EDOS, Empresas que Facturan Operaciones Simuladas y Empresas que Deducen Operaciones Simuladas. El contribuyente que recurra a la utilización de esta práctica de evasión y que es identificado por la autoridad competente, tendrá que acatarse al procedimiento establecido en el artículo 69-B del Código Fiscal de la Federación. El trabajo muestra el análisis de este procedimiento, y la relación que se tiene con una adecuada Cultura Tributaría, mediante la implementación de un adecuado Civismo Fiscal.
\end{abstract}

Cultura tributaria, Contribuciones, Impuestos, EFOS, EDOS

Citation: ANDRADE-OSEGUERA, Miguel Ángel, PAREDES-BARRÓN, Adriana and BÁRCENAS-PUENTE, José Luis. Analysis of article 69-B of the CFF and the tax culture. RINOE Journal - International Economy. 2020. 4-6:1-7.

\footnotetext{
* Correspondence to Author (Email: maandrade@utsoe.edu.mx)

$\dagger$ Researcher contributing first Author.
} 


\section{Introduction}

The work below shows an analysis of article 69$\mathrm{B}$ of the Federal Tax Code (CFF) and the tax culture of the country.

In 2014 the tax reform marked the appearance of article 69-B for the Federal Tax Code, this arises mainly because the SAT has an increasing presence in the electronic operations of taxpayers, which allows it to verify its own operations that they carry out and those they have with third parties, inside and outside the national territory.

The relevance of this analysis is to identify the impact of the implementation of this article and the application of the tax culture, so that taxpayers comply with their tax obligations and do so in a clear and transparent manner, as determined in the established regulations.

The implementation of article 69-B in the tax reform is mainly to identify, combat and reduce all those taxpayers who carry out evasive practices.

In this article we will observe some figures inherent to evasion practices, those that imitate and others that give tax effects, the authority colloquially calls them EFOS and EDOS, Companies that Invoice Simulated Operations and Companies that Deduct Simulated Operations.

Therefore, this article establishes what the taxpayer must do when in his operations he hires a supplier of goods or services that is published in the Official Gazette of the Federation (DOF) or on the SAT portal as a Company that Invoices Simulated Operations.

The tax culture that many taxpayers have when using this type of company can be said to be null, since they are undermining the integrity of their commercial operations, there are taxpayers who want to evade the Treasury and resort to these improper practices. Fiscal Citizenship is the responsible attitude, on the part of the citizen, in the fulfillment of tax obligations in a timely and voluntary manner. The Tax Culture is the set of values that are manifested in the permanent fulfillment of tax duties based on reason, trust and the affirmation of the values of personal ethics, with respect to the law, citizen responsibility and social solidarity of taxpayers. (SAT, 2018).
Complying with the obligations correctly is the way to contribute to public spending, sometimes it becomes difficult, and due to their own circumstances, there are taxpayers who resort to non-legal tax strategies, which affect their finances.

If the Tax Administration Service (SAT), were to detect that a taxpayer has allegedly issued tax receipts, it will have to abide by what article 69-B of the CFF says, which is the case of analysis of this investigation.

\section{Methodology to be developed}

The procedure established in article $69-\mathrm{B}$ of the Federal Tax Code is analyzed, which must be carried out by those taxpayers who incur in the aforementioned assumptions, likewise the analysis of the tax culture that is generated as a result of the improper practices established in the current regulations.

\section{Federation fiscal Code}

The new Fiscal Code of the Federation, published in the Official Gazette, updated on January 9, 2020, establishes in its article 69-B. When the tax authority detects that a taxpayer has been issuing vouchers without having the assets, personnel, infrastructure or material capacity, directly or indirectly, to provide the services or produce, commercialize or deliver the goods that would protect such vouchers, or that said taxpayers are not located, the nonexistence of the operations covered in such vouchers will be presumed.

In this case, it will proceed to notify taxpayers who are in this situation through their tax mailbox, the website of the Tax Administration Service, as well as through publication in the Official Gazette of the Federation, in order that those taxpayers can declare before the tax authority what their right is convenient and provide information that they consider pertinent to distort the facts that led the authority to notify them. To do this, interested taxpayers will have a period of fifteen days from the last of the notifications that have been made. (MPs, 2020) 
Article 69-B establishes that when the tax authority detects that a taxpayer has been issuing receipts without having the assets, personnel, infrastructure or material capacity, directly or indirectly, to provide the services or produce, commercialize or deliver the goods that protect such vouchers, or that said taxpayers are not located, the non-existence of the operations covered by such vouchers will be presumed.

In this case, it will proceed to notify taxpayers who are in this situation through their tax mailbox, the Internet page of the Tax Administration Service, as well as through publication in the Official Gazette of the Federation, in order to that those taxpayers can declare before the tax authority what is convenient for them and provide the documentation and information, they consider pertinent to distort the facts that led the authority to notify them. To do this, interested taxpayers will have a period of fifteen days from the last of the notifications that have been made. Taxpayers may request through the tax mailbox, on a single occasion, an extension of five days to the period provided for in the previous paragraph, to provide the respective documentation and information, as long as the request for an extension is made within said period. The extension requested in these terms will be understood to be granted without the need for a pronouncement by the authority and will begin to be computed from the day following the expiration of the term provided in the preceding paragraph.

After the deadline for providing documentation and information and, where appropriate, the extension, the authority, within a period that will not exceed fifty days, will assess the evidence and defenses that have been asserted and notify the taxpayers of their resolution. respective through the tax mailbox. Within the first twenty days of this period, the authority may require additional documentation and information from the taxpayer, which must be provided within the period of ten days after the notification of the tax mailbox requirement takes effect. In this case, the aforementioned period of fifty days will be suspended from the date the notification of the request takes effect and will resume the day after the said period of ten days expires.
Likewise, a list will be published in the Official Gazette of the Federation and on the Internet page of the Tax Administration Service, of the taxpayers who have not disproved the facts attributed to them and, therefore, are definitely in the situation at hand. referred to in the first paragraph of this article. In no case will this list be published before thirty days after notification of the resolution. The effects of the publication of this list will be to consider, with general effects, that the operations contained in the tax receipts issued by the taxpayer in question do not produce or produce any tax effect. The tax authority will also publish in the Official Gazette of the Federation and on the Internet page of the Tax Administration Service, on a quarterly basis, a list of those taxpayers who manage to disprove the facts that are imputed to them, as well as those who obtained a resolution or sentence firm that have annulled the resolution referred to in the fourth paragraph of this article, derived from the means of defense presented by the taxpayer. If the authority does not notify the corresponding resolution, within a period of fifty days, the presumption regarding the observed tax receipts, which gave rise to the procedure, will be void. Individuals or legal entities that have given any tax effect to the tax receipts issued by a taxpayer included in the list referred to in the fourth paragraph of this article, will have thirty days following the aforementioned publication to prove before the authority itself., who actually acquired the goods or received the services covered by the aforementioned tax receipts, or will proceed within the same period to correct their tax situation, through the corresponding complementary declaration or declarations, which they must present in terms of this Code. In the event that the tax authority, using its powers of verification, detects that a natural or legal person did not accredit the effective provision of the service or acquisition of the goods, or did not correct their tax situation, in the terms provided for in paragraph above, will determine the corresponding tax credit (s). Likewise, the operations covered by the aforementioned tax receipts will be considered as acts or simulated contracts for the purposes of the crimes provided for in this Code. (CENGAGE, 2020) 
In general terms, this article provides for the procedure by which a taxpayer hires a supplier that is published in the Official Gazette of the Federation as a Company that Invoices Simulated Operations (EFOS), the tax receipts are without tax effect, this indicates that the Expenditures made are not deductible for income tax nor are they creditable for value added tax with retroactive effects of 5 years. Once this has occurred, the EDOS have a period of 30 days to demonstrate the legality of their operations.

Clarifying terms, the EFOS (Company that Invoices Simulated Operations), are the companies that sell the invoices to be deducted by other companies that do have real operations.

EDOS (Company that Deducts Simulated Operations), are the companies that deduct the invoices obtained by EFOS to reduce the tax base and sometimes request refunds.

There are several assumptions that allow identifying the companies that are colloquially called billing companies, some characteristics are the following:

- They are recently created companies.

- They cannot be reached through the contact given to the SAT.

- There are no employees, machinery or inventory.

- There are two companies in the same tax domicile and they carry out operations with each other.

- There is no economic activity during verification visits.

- If they declare a small profit margin.

Mainly services are billed.

When the SAT detects that a taxpayer is falling into various assumptions, it will notify the taxpayer through the Tax Mailbox of the SAT, said Tax Mailbox must be activated by all Legal Persons and Individuals. If a taxpayer has worked with a collaborator or has carried out a transaction with an EDO or EFO, they will probably be notified first through the Tax Mailbox. (LOFTON, 2020)
Article 109 of the CFF in its section IV, states that the crimes of simulation of operations will be punished with the same penalty as the crime of tax fraud.

Article 108 of the same code defines the crime of tax fraud as: one who, with deception or taking advantage of errors, totally or partially omits the payment of a tax or obtains an undue benefit to the detriment of the federal treasury.

To know that an invoice is not false, it has the formal and authorized elements of every invoice. It is false when the Authority reviews the invoice and detects simulated operations that do not really exist.

They tend to pretend to pay when there is no such money, for tax evasion or when the money did exist, but for evasion or money laundering.

The SAT generates a blacklist where it publishes the list of taxpayers it has detected issuing CFDIs for non-existent operations, which it constantly updates and publishes it on its website. This allows taxpayers to verify if they have not carried out commercial operations with a Company that Deducts Simulated Operations that appears in said list and can prevent situations that may affect them.

It is recommended to be aware of the updates made by the SAT, the list of presumed and definitive ones constantly appears.

The operations carried out by the companies are real, they verify their operations before the SAT with the required documentation in a period of less than 30 business days.

Companies that carry out simulated operations must present the supplementary returns within a period of less than 30 business days to correct the tax situation, reducing the expense covered in the invoice and paying the taxes unduly deducted. (ProFact, 2020)

Companies that misuse invoices or digital tax receipts, do so to generate an increase in their operating expenses that allows them to deduct taxes.

The procedure that PRODECON establishes to carry out in the case of the cause established in article 69-B of the Federal Tax Code is the following:

ANDRADE-OSEGUERA, Miguel Ángel, PAREDESBARRÓN, Adriana and BÁRCENAS-PUENTE, José Luis. Analysis of article 69-B of the CFF and the tax culture. RINOE Journal - International Economv. 2020 


\section{Presumption of non-existence of operations}

Taxpayers who issue vouchers without having assets, people, infrastructure, material capacity to provide services or produce, commercialize or deliver the goods covered by the vouchers, as well as those that are not located (EFOS). The authority notifies this presumption.

Notification of the presumption

The authority notifies through:

- $\quad$ Tax Mailbox

- $\quad$ SAT website

- $\quad$ Official Gazette of the Federation (DOF).

Term of fifteen days to disprove the presumption. Two situations are generated:

- $\quad$ Did not provide documentation.

- $\quad$ If I provide documentation.

When you do not provide documentation, the following procedure is followed:

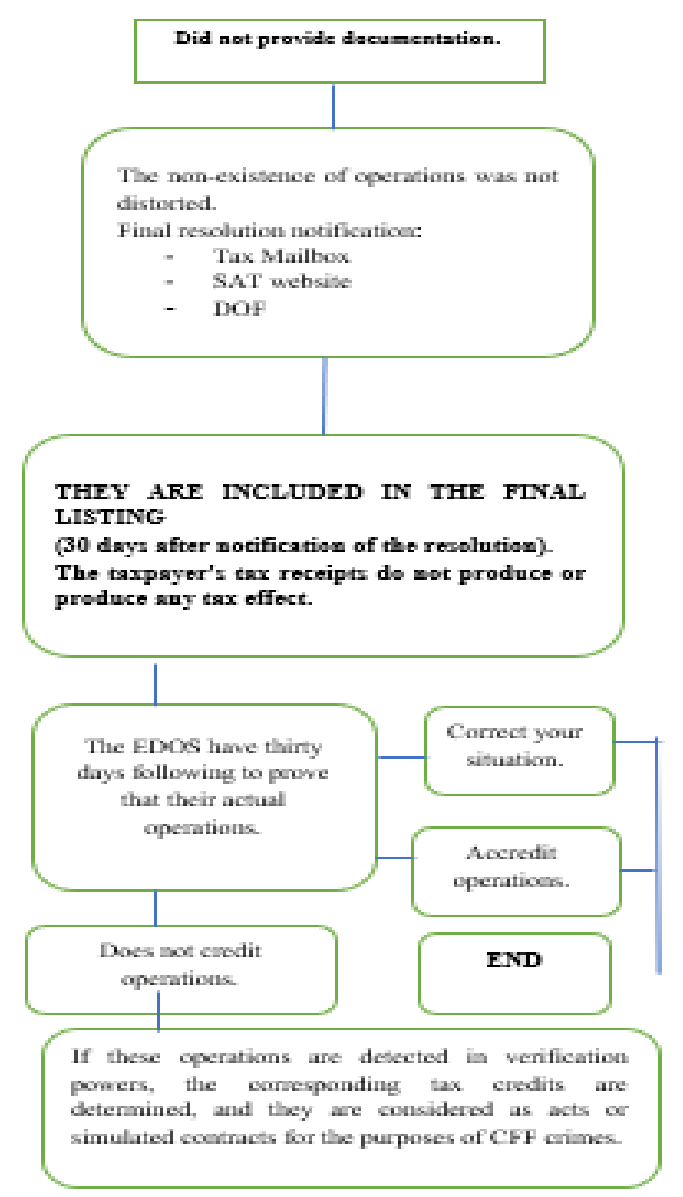

Figure 1 Process when you do not provide documentation Source PRODECON (PRODECON, 2020)
When if you provide documentation, the following procedure is followed:

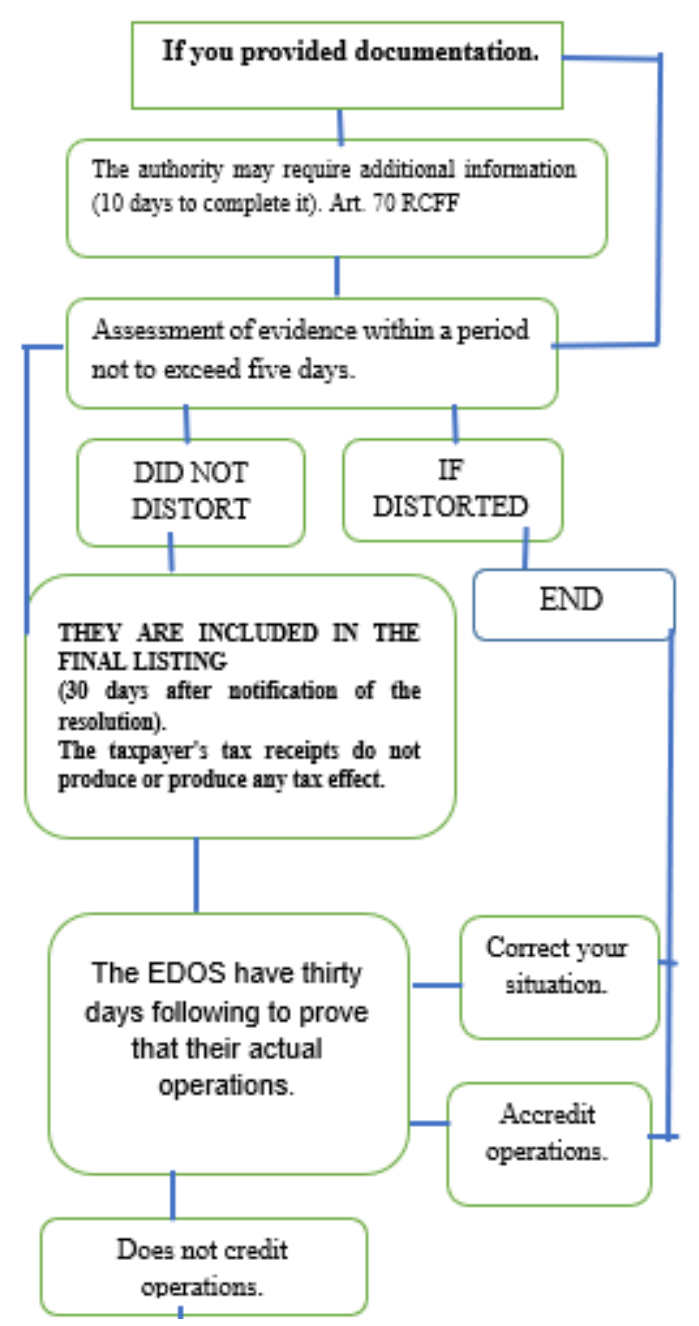

Figure 2 Process when you do not provide documentation Source: PRODECON (PRODECON, 2020)

For the crimes of Simulation of Operations and Tax Fraud, the sanction will be:

If the amount of the fraud cannot be determined, the penalty will be from three months to six years in prison.

The penalties may be reduced by up to fifty percent, if the amount of the fraud is immediately restored in a single exhibition. Both crimes can be classified according to their origin and will increase by one more half.

The amount of the defrauded contributions will be taken by fiscal year, except in provisional payments.

For the crimes of Simulation of Operation and Tax Fraud, the sanction will be as shown in table 1:

ANDRADE-OSEGUERA, Miguel Ángel, PAREDESBARRÓN, Adriana and BÁRCENAS-PUENTE, José Luis. Analysis of article 69-B of the CFF and the tax culture. RINOE Journal - International Economv. 2020 


\begin{tabular}{|l|l|}
\hline \multicolumn{1}{|c|}{ Prison } & \multicolumn{1}{|c|}{$\begin{array}{c}\text { Limit of the amount } \\
\text { Defrauded }\end{array}$} \\
\hline $\begin{array}{l}\text { From three months to two } \\
\text { years }\end{array}$ & Up to \$ 1,540,350.00 \\
\hline Two to five years & Up to $\$ 2,310,520.00$ \\
\hline Three to nine years & $\begin{array}{l}\text { When it exceeds } \\
2,310,520.00\end{array}$ \\
\hline
\end{tabular}

Table 1 Fraud amount limit

Source (Guillén A. C., 2018)

If the amount of the fraud cannot be determined, the penalty will be from three to six years in prison.

The amount of the defrauded contributions will be taken by fiscal year, except in provisional payments.

On the other hand, the Figure of Operations with Resources of illicit origin is typified in Title Twenty-Third, Chapters I and II of the Federal Criminal Code Articles 400, 400 Bis I, so that, when trying to hide illegal actions or resources of illicit origin, resort to Simulation of Legal Acts and Fictitious Operations, these crimes are prosecuted officially.

In particular, an indicator for the SAT stands out in the identification of evasive companies: when two taxpayers share the same email.

Sometimes it is complicated for several companies, in times of crisis, they are tempted to avoid paying contributions, hide information or develop strategies to reduce the amount of the contribution. (Guillén, 2018)

Money laundering, simulation and tax evasion are crimes that the government no longer allows to pass and in its fight against such fraudulent practices. The Tax Culture has an important participation with the activities mentioned, the ignorance of the taxpayers of the importance of the contributions and the consequence caused by said evasion, simulation or money laundering, generates the lack of compliance with tax obligations.

The Tax Culture is understood as the set of values, beliefs and attitudes, shared by a society regarding taxation and the laws that govern it, which leads to the permanent fulfillment of fiscal duties.
If we Mexicans had a teaching that shows us and explains the importance of obtaining knowledge about what contributions are at an early age with well-founded values and that this will generate a culture so that when we have to contribute to the State, Federation, Municipality we would do it recognizing that it is for the benefit of all, and in the same way if we were to occupy a public position where that resource has to be managed, we will do so with the corresponding ethics to improve our society and economy.

The creation of a Tax Tax Culture is not easy knowing similar cases as those indicated in the previous paragraphs. A good Fiscal Citizenship is the application of a responsible attitude, on the part of the taxpayers who carry out commercial activities, complying with the current regulations correctly, on time, attending to the values that allow the fulfillment of tax duties based on reason, trust and affirmation of ethics.

\section{Results}

The simulation occurs when the taxpayer has been issuing receipts despite not having the assets, personnel, infrastructure or material capacity, directly or indirectly, to provide the services or produce, market or deliver the goods that such receipts protect; or, that said taxpayers are not located, which gives rise to the presumption of the non-existence of operations in such vouchers.

The SAT keeps a control by means of statistics that show the behavior o the taxpayer, from the beginning of operations, the returns that he presents in a normal way, the number of complementary returns that he corrects, the variations in amounts and payments that he makes, then he crosses the information of the supplementary statements. Among other activities, the authority monitors and detects discrepancies based on the direct and indirect taxes or withholdings that were presented, monitors the compensation notices, graphs the income amounts for each month and compares results from previous years. (Guillén A. C., 2018)

Taxpayers who, due to lack of a solid Tax Culture, and due to ignorance or looking for invalid alternatives to pay less taxes, resort to using the services of the EDOS and EFOS. 


\section{Conclusions}

The importance of the subject of EDOS and EFOS and the consequences it generates for the companies that resort to them, the new provision regarding tax verification is generated, the frequent review of the list issued by the SAT, being a useful tool to consult from continuously, in order to provide security to the taxpayer in the course of their commercial activities.

The perception about tax evasion for many taxpayers is not clear, they do not dimension the problems that can be caused by the authority, the payment of contributions which, today it is of utmost importance to comply and be clear about the benefits that one has.

The authority is in constant vigilance and implementing actions to combat money laundering, and to detect taxpayers who commit the crime of tax fraud.

\section{References}

CENGAGE. (2020). Prontuario Fiscal 2020. México: CENGAGE.

DIPUTADOS, C. D. (June 10, 2020). http://www.diputados.gob.mx/LeyesBiblio/pdf/8 _090120.pdf. Obtained from http://www.diputados.gob.mx/LeyesBiblio/pdf/ 8_090120.pdf:

http://www.diputados.gob.mx/LeyesBiblio/pdf/ 8_090120.pdf

Guillén, A. C. (04 of 2018). expidefactura. Obtained from http://www.expidetufactura.com.mx/blog/efosedos-debes-saber-sus-implicaciones-legales/

Guillén, A. c. (04 of 2018). Soyconta. Obtenido de Soyconta: https://www.soyconta.com/efos-yedos-que-debes-saber-sobre-implicacioneslegales/

LOFTON. (25 of 10 of 2020). Obtained from LOFTON:

https://loftonsc.com/blog/juridico/juridico-

fiscal/que-son-los-efos-edos-sat/

PRODECON. (20 of 10 of 2020). PRODECON. Obtained from PRODECON: https://www.prodecon.gob.mx/Documentos/dia grama69b.pdf

ISSN-On line: 2524-2032

RINOE $^{\circledR}$ All rights reserved.
ProFact. (03 de 07 de 2020). Obtained from ProFact: https://profact.com.mx/efos-edos/

SAT. (12 de 12 de 2018). www.sat.gob.mx. Obtenido de www.sat.gob.mx: www.sat.gob.mx
ANDRADE-OSEGUERA, Miguel Ángel, PAREDESBARRÓN, Adriana and BÁRCENAS-PUENTE, José Luis. Analysis of article 69-B of the CFF and the tax culture. RINOE Journal - International Economv. 2020 